\title{
PENGARUH ALIRAN AIR SUNGAI BRANTAS TERHADAP PENDAPATAN PETANI DI DAERAH ALIRAN SUNGAI (DAS) BRANTAS KABUPATEN MOJOKERTO
}

\author{
Imam Baidlowi \\ Dosen Universitas Pesantren Tinggi Darul ‘Ulum Jombang
}

\begin{abstract}
Abstrak
Fokus penelitian ini adalah aliran air sungai Brantas dan Pendapatan Petani yang ada di Daerah Aliran Sungai (DAS) Brantas Kabupaten Mojokerto.

Permasalahan penelitian ini adalah mengidentifikasikan adanya penyebab turunya ketinggihan ketinngihan air sungai di Daerah Aliran Sungai (DAS) Brantas menyebabkan terjadinya perubahan pendapatan usaha tani , menaikkan biaya sosial masyarakat serta terjadinya kenaikan biaya produksi.

Tujuan penelitian ini adalah pertama, untuk mengetahui apakah terjadi perubahan pola tanam bagi petani padi terkait dengan penambangan pasir sungai Brantas di Kabupaten Mojokerto. Kedua untuk mengetahui apakah terjadi perubahan biaya produksi pertanian setelah terjadi penambangan pasir di sungai Brantas. Ketiga untuk mengetahui apakah terjadi perubahan pendapatan usaha tani dan biaya yang harus ditanggung masyarakat di daerah aliran sungai Brantas Kabupaten Mojokerto.

Hasil peneltian ini menunjukkan bahwa penambangan pasir sungai Brantas sebagai akibat dari turunya debet air sungai, sehingga permukaan air sungai Brantas lebih rendah dibandingkan dengan dasar anak sungai Brantas (sungai Kedungsoro). Akibatnya, air sungai Brantas tidak bisa mengalir ke sungai Kedungsoro apalagi ke parit hingga ke sawah (kerusakan lingkungan). Karena sulitnya untuk memperoleh air, maka petani tidak bisa menanam tanaman yang biasa ditanam yaitu padi - kedelai - tebu - jagung, karena kondisi tersebut menyebabkan para petani merubah pola tanamnya dari pola tanam padi - kedelai - tebu - jagung ke pola tanam tebu - tebu bero; tebu - tebu - padi; tebu - tebu - jagung; tebu - tebu - padi dan kedelai. Untuk memperoleh air dalam memenuhi kebutuhan tanaman dan pengerjaan sawah, petani berupaya untuk memenuhinya dengan cara mengebor tanah sawah dengan menggunakan mesin pompa. Mesin pompa untuk menyedot air, menjadikan biaya produksi usaha tani padi meningkat. Tambahan biaya yang dikeluarkan oleh para petani adalah biaya pembuatan sumur bor, pembelian atau menyewa pompa, pembelian solar dan pembayaran ongkos kerja penjaga pompa. Mengairi sawah dengan air sungai dan mengairi sawah dengan air pompa ternyata menjadikan hasil panen yang berbeda. Hasil panen dengan pengairan air sungai lebih bagus hasil panennya daripada pengerjaan sawah dengan air pompa. Dengan demikian, penambangan pasir sungan Brantas berdampak pada meningkatnya biaya produksi usaha tani dengan hasil panen yang relatif lebih rendah. Memperhatikan kondisi yang demikian maka dapat dinyatakan bahwa dampak tersebut ditunjukkan dengan meningkatnya social cost yang tinggi tidak sebanding dengan social benefitnya. Untuk menanggulanginya perlu adanya regulasi disertai kontrol masyarakat.
\end{abstract}

Kata Kunci: Aliran air sungai, Pendapatan Petani, Sungai Brantas

\begin{abstract}
The focus of this research is the Brantas river water flow and Farmers Income in Watershed (DAS) Brantas Mojokerto.

The problem of this research is to identify the cause of the fall of the river water ketinggihan ketinngihan Watershed (DAS) Brantas cause changes in farm income, increasing social costs as well as the increase in production costs.

The purpose of this study is the first to find out if there is a change cropping patterns for rice farmers associated with Brantas river sand mining in Mojokerto regency. The second to determine whether a change in the cost of agricultural production after the Brantas river sand mining. Third to determine whether a change in farm income and expenses to be borne by society in the watershed Brantas Mojokerto regency.

The results of this research indicate that the Brantas river sand mining as a result of debit and fall of river water, so the water level of the river Brantas lower than the child's basic Brantas River (river Kedungsoro). As a result, Brantas river water can not flow into the river Kedungsoro especially to trench down to the fields (environmental degradation). Because of the difficulty to obtain water, the farmers are unable to plant commonly grown are rice - soybean - sugarcane - maize, because these conditions cause farmers to change the pattern of cropping of cropping pattern of rice - soybean - sugar - corn into cropping sugar - cane - bero; sugarcane - sugarcane - rice; cane - sugar - corn; sugarcane - sugarcane - rice and soybeans. To get water to meet the needs of plants and construction fields, farmers seek to accomplish the drilling of paddy field by using pumps. Pumps to suck up the water, making rice farming production costs increased. Additional costs incurred
\end{abstract}


by farmers is the cost of making the wellbore, purchase or rent pumps, solar purchase and payment of labor costs pump guard. Irrigate with river water and irrigate with water pump turns making different crops. Yields with better irrigation, river water their crops than rice paddies with water pump workmanship. Thus, the sand mining sungan Brantas impact on increasing the production cost of farming with yields relatively low. Observing this condition, it can be stated that the effect is shown by the increasing high social cost is not proportional to social benefits. To mitigate the need for regulation with community control.

Keywords: river water flow, revenue Petani, Sungai Brantas

\section{PENDAHULUAN}

Kondisi aliran air di sungai Brantas wilayah Kabupaten Mojokerto pada saat ini sudah sangat memprihatinkan bagi masyarakat petani, hal ini disebabkan karena kondisi lingkungan yang sangat memprihatinkan, akibat dari penambangan pasir sungai berantas yang dilakukan beberapapa tahun lalu denga alasa demi memperlancar pelaksanaan pembangunan pembangunan dan tutntukan kebutuhan ekonomi. Namun akibat lain yang ditimbulkan dari penambangan pasir itu sangat berlebihan dan sangat merugikan perekonomian masyarakat petani dan kondisi lingkungan , seperti turunnya pendapatan petani serta rusaknya lingkungan alam sekitar.

Fokus Kajian Penelitian

Untuk memperjelas dan mempertajam fokus kajian penelitian ini, maka fokus penelitian disusun sebagai berikut:

1. Apakah ada perubahan pola tanam bagi petani padi di DAS Kabupaten Mojokerto?

2. Apakah ada perubahan biaya produksi pertanian bagi petani padi di DAS Kabupaten Mojokerto?

3. Apakah ada perubahan pendapatan bagi usaha tani di DAS Kabupaten Mojokerto?

4. Apaka ada biaya (social cost) yang harus ditanggung oleh masyarakat ?

Tujuan Penelitian

Penelitian yang lakukan ini ini bertujuan untuk:

1. Mengetahui perubahan pola tanam bagi petani padi terkait dengan penambangan pasir sungai Brantas di Kabupaten Mojokerto.

2. Mengetahui perubahan biaya produksi pertanian akibat dari kondisi aliran air di sungai Brantas.

3. Mengetahui perubahan pendapatan usaha tani padi di daerah aliran sungai Brantas Kabupaten Mojokerto.

4. Mengetahui biaya (social cost) yang harus ditanggung oleh masyarakat.

Manfaat Penelitian

Penelitian yang dilaksanakan ini diharapkan dapat memberikan manfaat :

1. Sebagai dasar pemikiran bagi masyarakat sekitar daerah aliran sungai Brantas dalam membangun perekonomian masyarakat petani pengguna air.

2. Sebagai bahan masukan bagi peneliti lain yang ingin melakukan penelitian lanjutan yang berkaitan dengan penambangan pasir sungai Brantas, kerusakan lingkungan alam, dan pendapatan usaha tani padi di daerah aliran sungai Brantas.

3. Perkembangan ilmu pengetahuan dan teknologi, khususnya di bidang Ilmu Ekonomi, yang berkonsentrasi pada Ilmu Ekonomi dan Studi Pembangunan yang beorientasi pada Pembangunan Ekonomi yang Bewawasan Lingkungan.

\section{TINJAUAN PUSTAKA}

Teori Ekonomi Lingkungan

Menurut pendapat Suparmoko (2000), Ekonomi lingkungan adalah ilmu yang mempelajari kegiatan manusia dalam memanfaatkan lingkungan sedemikian rupa sehingga fungsi/peranan lingkungan dapat dipertahankan atau bahkan dapat ditingkatkan dalam penggunaannya untuk jangka panjang. Dengan adanya berkembangnya waktu dan semakin meningkatnya pembangunan demi meningkatkan kesejahteraan manusia, ternyata fungsi/peranan lingkungan telah menurun dari waktu ke waktu karena banyak sumberdaya alam yang telah diubah fungsinya atau meningkatnya pencemaran.

Eksternalitas Lingkungan

Eksternalitas muncul apabila seseorang melakukan suatu kegiatan dan menimbulkan dampak pada orang lain dalam bentuk manfaat eksternalitas atau biaya eksternalitas yang semuanya tidak memerlukan kewajiban untuk menerima atau melakukan pembayaran. Dengan adanya manfaat eksternalitas atau biaya eksternalitas baik terhadap masyarakat dan lingkungan yang seringkali tidak diperhitungkan dalam pengambilan keputusan oleh seorang menejer tertentu.

Grinols (1994) menyatakan bahwa Barang publik dan eksternalitas keduanya meliputi berbagai 
situasi di mana penggunaannya atau produksi barang oleh agen produksi yang berpengaruh pada penggunaannya atau berpengaruh pada produksi yang lain, juga bisa melihat bagaimana pengaruh eksternalitas pada efisiensi pekerjaan atau sumberdaya yang ada dan apa yang perlu dilakukan untuk mengatasi masalah eksternalitas atau eksternalitas negatif akibat dari kegiatan produksi, juga bagaimana tentang kesediaan jumlah barang publik dan bagaimana masyakat akan membayarnya.

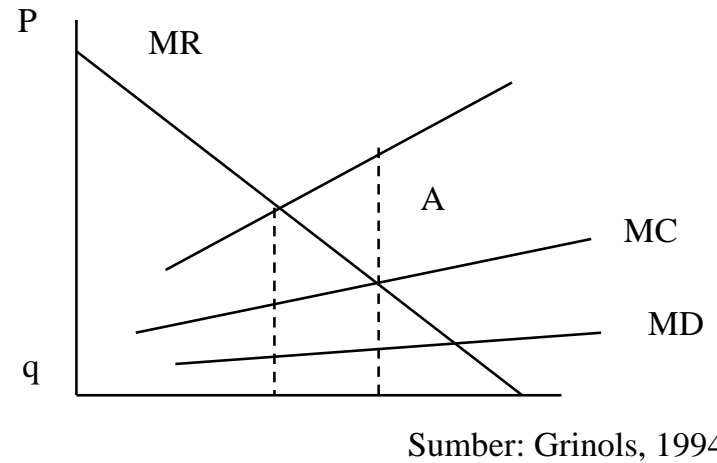

Gambar 1. Eksternalitas Negatif

Pendapatan yang Diperoleh dari Kegiatan Pemanfaatan Sumberdaya Alam

Tata perkembangan dunia industri dan pemanfaatan sumberdaya alam yang tanpa memperhatikan ekosistem maka secara eksternalitas akan mempengaruhi kondisi produktivitas industri lain atau tata kehidupan yang lain, misalnya alam dan tata lingkungan yang juga berpengaruh terhadap struktur perekonomian masyarakat terutama masyarakat pedesaan.

Biaya Produksi untuk Penambangan Sumberdaya Alam

Ricardo dalam Suparmoko (1997) berpendapat bahwa Produk pertanian ditentukan oleh biaya produksi dan sehubungan dengan meningkatnya biaya produksi untuk memenuhi kebutuhan masyarakat yang meningkat, harga produk harus meningkat sejalan dengan perluasan areal pertanaman dan penggunaan tanah subur yang semakin intensif.

Biaya Sosial (Social Cost) Akibat dari Pertambangan Sumberdaya Alam

Pendapat Mariam (2007), Kemampuan untuk memproduksi hasil yang terus menerus dengan tidak memperhatikan kerusakan sumberdaya alam yang terpilih maka akan menimbulkan kerusakan pada lingkungan lain termasuk lingkungan kehidupan manusia.

Brunette (2007) menyatakan Pengelolahan sumberdaya alam yang tidak teratur akan menimbulkan kerusakan alam yang pada akhirnya akan menyulitkan kehidupan makhluk hidup yang ada di lingkungan alam tersebut, termasuk hewan dan manusia.

\section{KERANGKA KONSEPTUAL PENELTIAN}

Berdasarkan rumusan masalah, tujuan penelitian, manfaat penelitian, dan tinjauan pustaka yang telah diuraikan sebelumnya, maka pada bagian ini dapat dikemukakan kerangka konseptual penelitian dan hipotesis sebagai berikut:

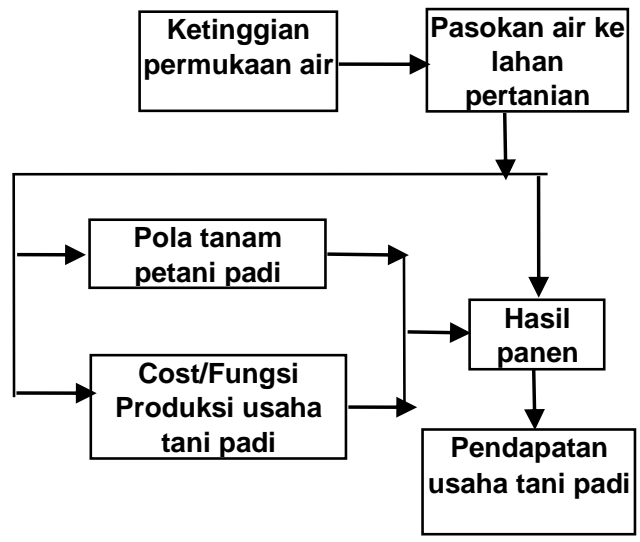

Gambar 2.Kerangka Pemikiran Penelitian

Turunnya debit air sungai berantas akibat dari Penambangan Pasir Sungai Brantas sehingga merubah Pola Tanam Petani

Turunnya debit air sungai brantas adalah disebabkan oleh Penambangan pasir di sungai Brantas adalah aktivitas sebagian kelompok orangorang tertentu dengan menggunakan ponton (mesin penyedot pasir) yang dimodali oleh perseorangan (pengusaha) untuk mengangkat pasir dari dasar sungai Brantas dalam jumlah yang besar untuk dijual ke wilayah Surabaya, Gresik, Sidoarjo, dan Mojokerto guna pembangunan gedung-gedung, jembatan, perumahan, bangunan cor atau tembok. Pasir sungai Brantas adalah termasuk pasir yang mempunyai klasifikasi yang cukup bagus sebagai bahan untuk membuat bangunan atau cor dibandingkan pasir yang berasal dari daerah gunung Bromo atau pasir laut yang berada di sepanjang pantai laut Jawa atau yang berasal dari daerah Kabupaten Lumajang.

Dengan turunnya debit air sungai berantas menjadikan perubahan terhadap Biaya Produksi Usaha Tani

Sistem dan tata guna pemanfaatan air untuk kepentingan kebutuhan tanaman di sawah bisa diartikan sebagai pengairan sawah. Pengairan sawah yang terjadi di DAS (Daerah Aliran Sungai) Brantas Kabupaten Mojokerto yang dulunya 
memanfaatkan aliran air dari Sungai Brantas, sekarang sudah tidak lagi bisa diandalkan karena kondisi air sungai Brantas yang debetnya sangat rendah sehingga tidak bisa lagi naik ke permukaan yang lebih tinggi, sehingga air tidak bisa lagi mengalir ke anak sungai hingga ke sawah.

Dampak Penambangan Pasir Sungai Brantas terhadap Pendapatan Usaha Tani Padi

Pendapatan yang diperoleh petani dari usaha tani padi yang bersumber dari hasil mengerjakan sawah yang ditanami padi dan tanaman lainnya yang dinyatakan dalam bentuk rupiah.

Turunnya debit air Sungai Brantas terhadap Social Cost yang Harus Ditanggung Petani

Biaya sosial yang harus ditanggung para petani padi adalan biaya yang disebabkan dari tidak bisanya air sungai Brantas masuk ke areal pertanian mereka. Biaya ini meliputi biaya untuk membuat sumur bor, mengadakan mesin pompa, membeli solar, dan tenaga kerja. Di samping itu, ada biaya lagi di antaranya para petani harus kehilangan beberapa tanaman yang ada di dalam pola tanamnya dan hilangnya sosial bubaya mereka yang selama ini sudah kebiasaan mereka.

\section{METODE PENELITIAN}

Secara umum penelitian ini untuk mendeskripsikan dan menganalisa turunnya debit air akibat dari penambangan pasir sungai brantas terhadap pola tanam petani, biaya produksi usaha tani padi, dan pendapatan usaha tani padi.

Pendapat Moleong (2008), Rancangan penelitian disusun melalui tiga tahap, di antaranya adalah: (1) tahap pra lapangan, (2) tahap kegiatan lapangan, dan (3) analisis dan uji keabsahan.

1. Tahap Pra-lapangan

2. Tahap Kegiatan Lapangan

3. Analisis dan Uji keabsahan

Dalam memperoleh sumber data dikelompokan menjadi dua, yaitu data primer dan data sekunder. Data primer meliputi hasil wawancara dengan para informan dan hasil pengamatan lapangan yang berupa catatan lapangan, rekaman suara wawancara

1. Informan

2. Dokumen

3. Pengumpulan data: wawancara, pengamatan, studi dokumen.

Data yang telah dipeoleh dianalisis secara kritis dan logis sesuai dengan kondisi sosial setempat. Interpretasi secara sistematis sesuai dengan penelitian kuantitatif. Data yang diperoleh di lapangan dalam bentuk narasi dan argumen kuantitatif akan dirinci dengan baik agar dapat membuat sehingga dapat ditarik suatu kesimpulan dengan tepat.

Keabsaan data pada penelitian ini menggunakan empat standar kriteria yang diangggap mampu menjamin keabsahan hasil penelitian kualitatif.

Tempat atau lokasi penelitian adalah di Desa Balongsari Kecamatan Gedeg Kabupaten Mojokerto. Dipilih lokasi ini karena desa Balongsari terletak di utara sungai Brantas yang merupakan Daerah Aliran Sungai (DAS) di perbatasan antara Kecamatan Gedeg dan Jetis serta paling dekat dengan kecamatan Kemlagi.

Waktu penelitian adalah pada akhir tahun 2015 sampai dengan awal tahun 2016. Dipilih pada waktu tersebut, karena di setiap akhir dan awal tahun atau bulan Oktober sampai dengan Maret atau April adalah akhir musim kemarau dan awal musim hujan. Di saat itulah para petani memanen hasil tanaman usahanya atau memulai bercocok tanam.

\section{HASIL DAN PEMBAHASAN}

Pada bab ini disajikan tentang hasil penelitian lapangan yang merupakan kondisi obyektif yang ditemukan di lapangan dan merupakan gambaran kondisi penurunan debit air sungai Brantas, pola tanam petani padi sebelum dan sesudah penurunan debit air, biaya produksi usaha tani padi sebelum dan sesudah penambangan pasir, dan pendapatan usaha tani padi sebelum dan sesudah penambangan pasir sungai Brantas.

Penuruan ketinggihan debit air Sungai Brantas akibat dari Penurunan debit air di sungai Brantas pada saat ini sudah pada kondisi yang sangat memprihatinkan, sebab teknik pengambilan pasir dari dasar sungai Brantas sudah tidak lagi. Sekarang para penambang sudah tidak menggunakan keranjang lagi, tetapi menggunakan mesin penyedot pasir (ponton) yang diletakkan di atas pengapung dengan posisi di tengah atau di tepi sungai.

Pola tanam petani padi di Desa Balongsari Kecamatan Gedeg Kabupaten Mojokerto ini sangat dipengaruhi oleh sistem pengairan yang ada teknik atau sistem pengairan. Tanaman para petani yang ada di desa ini pada umumnya mempengaruhi pola tanam yang membutuhkan air yang cukup misalnya padi, jagung, kedelai, dan tebu.

Pola tanam petani padi yang ada di daerah 
penelitian sebelum penurunan debit air sungai Brantas pada umumnya dilakukan secara bersamabersama.

Sesudah terjadi penambangan pasir di sungai Brantas, maka pola tanam para petani padi dalam satu desa atau satu daerah persawahan tidak serempak satu macam tanaman dalam satu musim tanam seperti sebelumnya, tetapi beraneka ragam. Ada yang ditanami tebu, padi, jagung, kedelai, ada yang baru dicangkul, ada yang dibiarkan bero bertahun-tahuin bahkan puluhan tahun.

Biaya produksi untuk usaha tani padi dalam satu kali pola tanam adalah meliputi biaya yang dikeluarkan untuk tenaga kerja, pengadaan bibit, pengadaan pupuk, dan pengadaan obat-obatan. Untuk biaya produksi setelah adanya penurunan debit air, ada lagi biaya yang harus dikeluarkan, yaitu biaya untuk pengairan atau biaya dikeluarkan untuk mengadakan air yang digunakan mengairi sawah.

Sebelum penurunan debit air sungai Brantas petani mampu melaksanakan 4 (empat) kali tanam meliputi 4 (empat) macam tanaman, yaitu: padi, kedelai, tebu, dan jagung. Biaya produksi yang dikeluarkan meliputi biaya pengadaan bibit, biaya pengadaan pupuk, biaya pengadaan obat-obatan, dan biaya untuk tenaga kerja. Jumlah besarnya biaya antara tanaman satu dengan tanaman lainnya berbeda.

Biaya produksi petani padi setelah adanya penurunan debit air sungai Brantas dibandingkan dengan sebelum adanya penambangan pasir sungai Brantas telah mengalami perubahan yang sangat berarti yang dirasakan bagi para petani padi, terutama biaya untuk pengairan yang dulu sebelum adanya penambangan pasir tidak perlu ada biaya untuk mengairi sawah, tetapi setelah adanya penambangan pasir, untuk mengairi sawah harus ada biayanya.

Perubahan sistem pengairan nampaknya membawa pengaruh terhadap biaya yang dikeluarkan oleh petani dalam bercocok tanam.

Hasil Usaha tani padi adalah hasil yang diperoleh dari usaha mengolah tanah pertanian yang ditanami padi dan tanaman lainnya dalam satu kali pola tanam. Dalam satu kali pola tanam padi pada umumnya tanaman yang ditanam di sawah itu tidak hanya padi saja, tetapi ada rangkaian tanaman lain yang menjadi pelengkap dalam satu kali pola tanam.

Hasil produksi usaha tani padi sebelum adanya penambangan pasir sungai Brantas adalah produksi panen yang diperoleh dari usaha tani sebelum adanya penambangan pasir sungai Brantas yang dihitung berdasarkan harga saat ini.

Pola tanam sebelum adanya penambangan pasir dibandingkan sesudah adanya penurunan debit air mempunyai perbedaan yang cukup menyolok, hal ini dipengaruhi oleh pola tanam dan sistem pengairan. Hal tersebut dapat dilihat dari jumlah tanaman yang ditanam oleh petani dan kondisi pemeliharaan tanaman yang dilakukan oleh para petani. Panen yang sering dijumpai pada daerah pertanian yang ada di daerah aliran sungai Brantas adalah panen padi dan tebu.

Kondisi penambangan tata pasir sungai Brantas telah banyak mempengaruhi kehipan masyakat DAS Brantas Kebupaten Mojokerto baik secara sosial, ekonomi, maupun budaya. Tidak mengalirnya aliran sungai Brantas ke anak sungai (sungai Kedungsoro) telah banyak merubah segi kehidupan masyarakat yang ada.

Kondisi sosial masyarakat berdasarkan informan kunci, maka data yang ada di Histrogram Desa Balongsari telah terjadi berbagai perubahan di dalam kehidupan masyarakat petani.

Perekonomian masyarakat DAS Brantas Kabupaten Mojokerto sebelum penambangan pasir mayoritas masyarakatnya bekerja di sektor pertanian. Menurut informan kunci bahwa masyarakat DAS Kabupaten Mojokerto, sebagian besarnya penduduk desa ini tinggal dan bekerja di desa ini pula. Penambangan pasir sungai Brantas sudah tidak lagi memperhatikan keseimbangan alam termasuk kerusakan alam. Kondisi sungai Brantas saat ini sudah tidak bisa lagi mengalir ke beberapa anak sungai karena permukaan air sungai Brantas sudah ada di bawah dasar anak sungai. Hal ini menyebabkan banyak anak sungai yang menjadi kering, selokan, parit-parit menjadi mati karena lama tidak dialiri oleh air. Berdasarkan hasil pengamatan yang peneliti lakukan mulai 31 Maret sampai dengan 2 April 2007 bahwa setiap hari pasir sungai Brantas diangkut oleh truk menuju luar daerah Kabupaten Mojokerto rata-rata \pm 51 truk sampai dengan 60 truk.

Pola tanam petani padi di DAS Brantas Kabupaten Mojokerto banyak dipengaruhi oleh sistem pengairan yang ada. Pengairan sawah petani padi pada waktu sebelum terjadi penambangan pasir sungai Brantas semua petani di DAS hanya mengandalkan pasokan air sungai Brantas untuk mengairi sawah.

Pola tanam petani padi yang ada di DAS 
Brantas Kabupaten Mojokerto sebelum adanya penurunan debit air sungai Brantas pada umumnya dijalani oleh para petani padi dengan cara dan waktu bersama-sama, dalam arti waktu tanamnya sama dan jenis tanamannya yang ditanam juga sama.

Penambangan pasir sungai Brantas di Kabupaten Mojokerto ternyata membawa dampak terhadap turunnya debit air sehingga merubah pola tanam petani di DAS Brantas Kabupaten Mojokerto. Setelah terjadi penambangan, pola tanam petani padi di DAS Brantas Kabupaten Mojokerto telah mengalami perubahan.

Biaya produksi petani padi sebelum adanya penurunan debit air sungai Brantas adalah sanagat ringan sekali, sebab di samping tidak ada biaya untuk pengairan, kebutuhan pemupukan sangat ringan sekali juga termasuk hasil panen tanamannya. Berdasarkan hasil penelitian di lapangan, biaya produksi pertanian dalam satu kali pola tanam menunjukkan bahwa biaya produksi yang dikeluarkan antara petani padi satu dengan petani padi lainnya semuanya menjawab dengan jawaban yang sama

Biaya produksi petani padi setelah adanya penurunan air sungai Brantas ternyata mengalami peningkatan peningkatan yang cukup berarti bagi petani. Berdasarkan hasil penelitian di lapangan ada beberapa kegiatan fungsi produksi yang dulu sebelum adanya penambangan pasir tidak ada, tetapi sekarang ada.

Berdasarkan hasil penelitian di lapangan yang didukung hasil kuisioner bahwa sebelum adanya penambangan pasir sungai Brantas yang brakibat turunya debit air, maka para petani padi di daerah sampel dapat menanami sawahnya dengan empat macam tanaman dalam satu kali pola tanam, meliputi tanaman padi, kedelai, tebu, dan jagung. Empat macam tanaman tersebut merupakan jenis tanaman yang ditanam oleh para petani secara keseluruan.

Hasil panen usaha tani padi setelah adanya penurunan debit air sungai Brantas antara petani satu dengan petani lainnya bervariatif. Hal ini disebabkan jenis tanaman yang ditanam oleh petani satu dengan lainnya tidak sama, seperti tanaman tebu para petani menanam sampai dua kali dan setelah itu dibiarkan bero, tetapi ada yang setelah menanam tebu dua kali terus ditanami padi, ada yang setelah tebu dua kali terus ditanami jagung, dan ada yang setelah tebu dua kali terus ditanami padi dan kedelai. Untuk itu hasil panennya juga tidak sama, termasuk musim panennya.

Pendapatan usaha tani padi sebelum adanya penurunan debit air sungai Brantas dan setelah adanya penambangan pasir sungai Brantas memang mengalami perubahan pendapatan petani.

Tabel 1. Pendapatan Usaha Tani Sebelum Adanya Penurunan debit air Sungai Brantas yang Dihitung per Hektar

\begin{tabular}{|c|c|c|c|c|c|c|c|c|c|}
\hline $\begin{array}{l}\text { Tana } \\
\text { man } \\
\text { (Rp) }\end{array}$ & & adi & & $\begin{array}{l}\text { edela } \\
\text { i }\end{array}$ & & Tebu & & $\begin{array}{l}\text { agun } \\
\text { g }\end{array}$ & $\begin{array}{c}\text { Jum } \\
\text { lah }\end{array}$ \\
\hline $\begin{array}{l}\text { Satu } \\
\text { an }\end{array}$ & Kg & $\mathbf{R p}$ & $\mathbf{K g}$ & $\mathbf{R p}$ & $\mathbf{K g}$ & Rp & Kg & $\mathbf{R p}$ & \\
\hline $\begin{array}{l}\text { Jumlah } \\
\text { biaya }\end{array}$ & & $\begin{array}{c}2,163 \\
, 000\end{array}$ & & $\begin{array}{c}967.5 \\
00\end{array}$ & & $\begin{array}{c}5,580 \\
000\end{array}$ & & $\begin{array}{c}1,700 \\
, 000\end{array}$ & $\begin{array}{c}10,410 \\
500\end{array}$ \\
\hline $\begin{array}{l}\text { Hasil } \\
\text { Pane } \\
\mathrm{n}\end{array}$ & $\begin{array}{c}800 \\
0\end{array}$ & $\begin{array}{l}17,60 \\
0.000\end{array}$ & $\begin{array}{c}100 \\
0\end{array}$ & $\begin{array}{c}4,000 \\
, 000\end{array}$ & $\begin{array}{c}11,00 \\
0\end{array}$ & $\begin{array}{c}27,500 \\
, 000\end{array}$ & $\begin{array}{c}4,50 \\
0\end{array}$ & $\begin{array}{c}8,100 \\
, 000\end{array}$ & $\begin{array}{c}57,200 \\
000\end{array}$ \\
\hline $\begin{array}{l}\text { Pend } \\
\text { apata } \\
\mathrm{n}\end{array}$ & & $\begin{array}{c}15,4 \\
37.0 \\
00\end{array}$ & & $\begin{array}{c}3,03 \\
2,50 \\
0\end{array}$ & & $\begin{array}{l}21,92 \\
0,000\end{array}$ & & $\begin{array}{c}6,40 \\
0,00 \\
0\end{array}$ & $\begin{array}{l}46,78 \\
9,500\end{array}$ \\
\hline
\end{tabular}

Sumber: Data dari Informan

Tabel 2. Perbandingan Pendapatan Usaha Tani Sebelum dan Sesudah Adanya Penurunan debit air Sungai Brantas yang Dihitung per Hektar Sawah

\begin{tabular}{llcc}
\hline & \multicolumn{1}{c}{ Jenis } & \multicolumn{2}{c}{ Pendapatan } \\
No & Tanaman & $\begin{array}{c}\text { Selum } \\
\text { Penambangan } \\
\text { Pasir (Rp) }\end{array}$ & $\begin{array}{c}\text { Sesudah } \\
\text { Penambangan } \\
\text { Pasir (Rp) }\end{array}$ \\
\hline 1. & Padi & 15.437 .000 & 4.075 .000 \\
2. & Kedelai & 3.032 .500 & 2.792 .500 \\
3. & Tebu & 21.920 .000 & 21.365 .000 \\
4. & Jagung & 6.400 .000 & 3.017 .500 \\
\hline
\end{tabular}

Sumber: Data Perkembangan Ekonomi Desa

Penurunan pendapatan hasil tanam yang paling menonjol adalah penurunan pendapatan hasil tanam padi, yaitu rata-rata $73,6 \%$ dan yang paling sedikit penurunan pendapatannya adalah pendapatan hasil tanaman tebu, yaitu 2,53. Para petani dalam mengelola sawahnya banyak menanami sawahnya dengan tanaman tebu, karena dianggap paling menguntungkan dibandingkan dengan tanaman lainnya.

Untuk mengatasi ini para menggunakan sumur bor dan mesin pompa dalam mengairi sawahnya, tetapi pengairan semacam ini di samping biayanya mahal karena harus mengebor tanah, membeli mesin pompa atau menyewa, membeli solar dan membayar tenaga kerja. Air yang dipeoleh mengiri sawah tidak cukup, maka banyak petani padi yang tidak lagi menanam padi. Dari 
petani yang menjadi informan, hanya ada 1 petani yang masih bertahan menanam padi, itu menurut pengakuan mereka karena terpaksa dari pada tidak ada pekerjaan lain. Kesultan air telah merubah pola tanam petani padi, dari 4 macam tanaman menjadi kurang dari 4 atau dibiarkan bero (tanpa tanaman).

Sebelum penambangan pasir masyarakat sekitar sungai bisa mencari ikan di anak sungai dengan cara mengail, mlintur (mencari udang dengan memasang keranjang di tepi anak sungai), nyamber (menjaring ikan dari tepi anak sungai), njolo (menjaring ikan), munggut (mencari ikan di anak sungai bersama-sama) itu semua sudah tidak ada lagi.

Sungai Kedungsoro (anak sungai Brantas) saat ini sudah kering, dasar sungai oleh masyarakat tertentu digunakan membuat batu merah, sebagian dipakai mendirikan rumah penduduk, sebagian lagi untuk ditanami ubi kayu dan jagung. Fungsi sungai telah berubah secara total. Sungai Kedungsoro bukan lagi sebagai infrastuktur irigasi bagi lahan pertanian, tetapi pekarangan rumah penduduk, ladang pendidik, dan lahan pembuatan batu merah.

\section{PENUTUP}

Kesimpulan

1. Turunnya debit air akibat adanya penambangan pasir di Sungai Brantas menyebabkan para petani merubah pola tanam yang semula 4 (empat) macam tanaman dalam satu kali pola tanam menjadi kurang dari empat, bahkan satu macam tanaman, sehingga terdapat kondisi sawah dibiarkan bero. Perubahan pola tanam ini disebabkan oleh adanya perubahan sistim pengairan. Saat sawah dalam keadaan bero, para petani harus mencari pekerjaan lain di luar pertanian. Selain akibat-akibat di atas ada akibat lain yang harus ditanggung oleh masyarakat.

2. Untuk memenuhi kebutuhan pengairan sawah para petani harus membuat sumur bor dan memakai pompa, membeli solar, dan membayar tenaga kerja untuk mengalirkan air ke sawahnya. Perubahan ini juga berpengaruh pada kebutuhan pupuk dan obat-obatan yang semakin meningkat dibandingkan dengan menggunakan air sungai, yang berakibat biaya produksi semakin tinggi.

3. Sementara itu hasil panen semakin menurun, karena pengairan dengan menggunakan sumur bor mengurangi kesuburan tanaman yang disebabkan oleh kandungan unsur hara air bor lebih rendah dibandingkan dengan air sungai sehingga hasil produksi pertanian menjadi turun.

4. Biaya sosial (social cost) yang harus ditanggung masyarakat sebagai akibat dari penambangan pasir semakin meningkat, terutama masyarakat petani karena untuk mengairi sawah harus mengebor dan memompa air.

Saran

1. Bila mungkin Pemerintah Daerah seharusnya membuat Perda tentang Penambangan Pasir dengan pajak yang setinggi-tingginya dan pajak itu digunakan untuk membangun fasilitas masyarakat sebagai ganti biaya yang masyarakat keluarkan akibat dari penambangan pasir.

2. Pentingnya konservasi fungsi air sungai Brantas bagi areal pertanian, dapat dilakukan dengan memperketat pemanfaatan sungai Brantas dengan regulasi disertai kontrol masyarakat kepada pengusaha.

3. Dengan beban biaya akibat dari kurangnya air di sawah, maka petani bisa memanfaatkannya dengan menanam tebu yang dianggap tidak banyak membutuhkan perawatan dan harga jual yang lebih tinggi serta mudah penjualan terhadap hasil panennya.

\section{DAFTAR PUSTAKA}

Grinols, Earl, L. 1994, Microeconomics, Copyright (C) 1994 by Houghton Mifflin Company, All rights reserved, Printed in the USA.

Moeleong, Lexy, J., 2000, Metodologi Penelitian Kuantitatif, PT. Remaja Rosdakarya, Bandung.

Suparmoko, M.,2000, Ekonomi Sumberdaya Alam dan Lingkungan, PT. BPFE, Yogyakarta.

Suparmoko, M., 2000, Ekonomika Lingkungan, BPFE, Yogyakarta.

Usman, Husaini dkk., 2003, Metodologi

Brunette, Marielle, dkk, 2007, Hedging Strategies in Forest Management, online at http://mpra.Ub.Uni-

muenchen.De/5228/MPRA Paper No.5228, posted 07. Nopember 2007.

Mariam, Yohannes, 2012, The Implication of Incorporating Environmental Costs in Utility Rate Setting, online at http://mpraub.Unimuenchen.De/412/MPRA Paper No. 412, posted 07. Nopember 2007. 